\title{
Antioxidant activity of oils extracted from orange (Citrus sinensis) seeds
}

\author{
NEUZA JORGE, ANA CAROLINA DA SILVA and CAROLINE P.M. ARANHA \\ Departamento de Engenharia e Tecnologia em Alimentos, Universidade Estadual de São Paulo, Rua \\ Cristóvão Colombo, 2265, Jardim Nazareth, 15054-000 São José do Rio Preto, SP, Brasil \\ Manuscript received on November 25, 2014; accepted for publication on February 24, 2015
}

\begin{abstract}
Due to the increasing production of food in the world with consequent increase of the production of waste, the importance of developing researches for its use is noticed. Thus, the interest in vegetable oils with bioactive compounds, such as the ones extracted from fruit seeds, is growing. Therefore, the present study aims to characterize the oils extracted from seeds of Hamlin, Natal, Pera-rio and Valencia orange varieties (Citrus sinensis), as to the levels of total carotenoids, total phenolic compounds, tocopherols and phytosterols, as well as to determine their antioxidant activity. The orange seed oils presented important content of total carotenoids $(19.01 \mathrm{mg} / \mathrm{kg})$, total phenolic compounds $(4.43 \mathrm{~g} / \mathrm{kg}), \alpha$-tocopherol $(135.65$ $\mathrm{mg} / \mathrm{kg}$ ) and phytosterols (1304.2 mg/kg). The antioxidant activity ranged from $56.0 \%$ (Natal) to $70.2 \%$ (Pera-rio). According to the results it is possible to conclude that the orange seed oils can be used as specialty oils in diet, since they contain considerable amounts of bioactive compounds and antioxidants.
\end{abstract}

Key words: agro-industrial waste, phytosterols, tocopherols, vegetable oils.

\section{INTRODUCTION}

The citrus industry has great potential for growth, and is one of the most competitive agricultural sectors. Orange varieties such as Hamlin, Natal, Pera-rio, and Valencia belong to the species Citrus sinensis (L.) Osbeck, which is mainly characterized for its sweet taste. The flowers and fruits of these oranges are smaller, and have thinner peel and albedo (Koller 2006). Orange is extensively processed in order to obtain natural juices, pulps, candies, and extracts for manufacturing industries. However, wastes generated by the processing of orange, represent approximately $50 \%$ of the fruits (Hernández-Montoya et al. 2009). With

Correspondence to: Neuza Jorge

E-mail: njorge@ibilce.unesp.br the intention of adding value to those wastes and minimizing environmental impacts, the use of these sub-products is essential, since they present great potential for application in food, pharmaceutical, and cosmetic industries (Schieber et al. 2001).

The waste may contain compounds that are capable of providing benefits to health, by preventing diseases or even favoring the functioning of the body, which are called bioactive compounds. Such substances perform several functions from a biological point of view, such as antioxidant activity, modulation of detoxification enzymes, stimulation of the immune system, reduction of platelet aggregation, antibacterial and antiviral activities (Schmidt and Pokorný 2005). The vegetable oils are considered sources of these compounds, especially 
carotenoids, phenolic compounds, tocopherols, and phytosterols.

The seeds of fruits such as oranges (Citrus sinensis) are shown to be promising sources of oils, rich in carotenoids, phenolic compounds, tocopherols, and phytosterols. For this reason, a study to quantify the presence of these compounds in oils extracted from the mentioned fruits is important, in order to use them as specialty oils (Malacrida et al. 2012).

\section{MATERIALS AND METHODS}

\section{PLANT MATERIALS}

In the present study, seeds of the orange varieties Hamlin, Natal, Pera-rio, and Valencia were used, since they are the most employed types in the production of juice in the state of São Paulo, Brazil. Three batches of waste of each variety were acquired between June and August, in the harvest of 2010, from Indústria Suco Cítrico Cutrale Uchôa, São Paulo, Brazil. Immediately after receipt of the waste, the seeds were manually separated from peels and pulp, and dried for approximately $96 \mathrm{~h}$, on trays, at room temperature for moisture reduction $(<10 \%)$. The batches of each variety of orange seeds, which weighed around 800-850 g, homogenized, packed in rigid plastic polypropylene packaging, sealed with screw caps and properly labeled for further analysis.

\section{EXTRACTION OF OILS FROM THE SEEDS}

The oils were obtained by pressing in vegetable oil extractor; brand Brazil Metal Wilhelms (Porto Alegre, Brazil), at room temperature, with initial rotation of $25 \mathrm{~Hz}$ and final rotation of $60 \mathrm{~Hz}$, approximately. After extraction, the oils were placed in amber glass bottles with nitrogen gas and stored at $-18{ }^{\circ} \mathrm{C}$ for further analysis.

\section{ANTIOXIDANT PROPERTIES}

Total carotenoids were determined by spectrophotometry, according to the method described by
Rodriguez-Amaya (1999). The quantification was performed in a UV-vis spectrophotometer (Shimadzu, Kyoto, Japan), with wavelength interval from $300 \mathrm{~nm}$ to $550 \mathrm{~nm}$. Quantification was measured by absorption wavelength of maximum absorbance and absorptivity value of 2592 in petroleum ether, expressed as milligrams of $\beta$-carotene per kilogram.

The total phenolic compounds were extracted from the oil samples according to the procedure described by Parry et al. (2005) and quantified by spectrophotometry, using Folin-Ciocalteu reagent (Singleton and Rossi 1965), through calibration curve with gallic acid as standard. The levels of total phenolic compounds in oils were expressed as grams of gallic acid equivalents (GAE) per kilogram of oil.

The determination of tocopherols was performed according to the method AOCS Ce 8-89 (2009), by high performance liquid chromatography (HPLC), using a Varian model 210-263 (Varian, Palo Alto, California, USA), with fluorescence detector. The quantification was carried out by external standardization and the values were determined based on peak areas and expressed in values of each isomer, separately, in milligrams per kilogram.

The contents of phytosterols extracted from the seeds were determined by gas chromatography, with previous saponification of the samples. Saponification was performed according to the method published by Duchateau et al. (2002). For the determinations of phytosterols, the method AOCS Ch 6-91 (2009) was used, with adaptations. The analyses were carried out in a gas chromatograph, model CG 2010-Plus (Shimadzu, Tokyo, Japan), equipped with a flame-ionization detector, split-splitless injector, and an autosampler. The compounds were separated in a fused silica capillary column (Restek RTX 5, Shimadzu), 30 m length, $0.25 \mathrm{~mm}$ internal diameter, and $0.25 \mu \mathrm{m}$ film thickness. The programming of the temperature 
column was initiated at $100{ }^{\circ} \mathrm{C}$, for $2 \mathrm{~min}$, heated at $15^{\circ} \mathrm{C} / \mathrm{min}$ until $260^{\circ} \mathrm{C}$, and kept isothermal for 35 $\mathrm{min}$. The temperatures used in the injector and in the detector were 280 and $320^{\circ} \mathrm{C}$, respectively. The carrier gas was hydrogen with linear velocity of 40 $\mathrm{ml} / \mathrm{min}$. Samples of $1.0 \mu \mathrm{L}$ were injected with split ratio of 1:50. Sterols (cholesterol, campesterol, stigmasterol, $\beta$-sitosterol, and stigmastanol) were identified by comparison with the retention time of pure standards (Supelco, Bellefonte, Pennsylvania, USA), analyzed under the same conditions of the samples. The quantification of each isomer was performed by internal standardization ( $5 \alpha$-cholestano-3 $\beta$-ol), based on the peak areas.

The antioxidant activity of the oils was determined according to the method described by Kalantzakis et al. (2006). This method consists in evaluating the scavenging activity of the free radical 2,2-diphenyl-1-picrylhydrazyl (DPPH'). To determine the antioxidant activity of the oils, $1 \mathrm{~g}$ of oil was diluted with $10 \mathrm{ml}$ of ethyl acetate. From this solution, $1 \mathrm{ml}$ was added to $4 \mathrm{ml}$ of a $\mathrm{DPPH}^{\bullet}$ solution, in $10^{-4} \mathrm{~mol} / \mathrm{l}$ ethyl acetate, and was vigorously shaken in vortex, for $10 \mathrm{sec}$. After $30 \mathrm{~min}$ in the dark, the mixture absorbance was measured at $517 \mathrm{~nm}$. A control sample (without oil) was prepared and the absorbance was equally measured. The levels of absorbance obtained were converted to percentage of antioxidant activity (AA).
The efficient concentration (EC), defined as the sufficient concentration to obtain $50 \%$ of the maximum effect estimated in 100\% (expressed in kilograms of oil per kilogram of $\mathrm{DPPH}^{\circ}$ ), was graphically determined. To do so, oil samples were diluted with ethyl acetate in concentrations of $10,25,50,75$, and $100 \mathrm{mg} / \mathrm{ml}$. Measurements of the absorbance of reaction mixtures $(1 \mathrm{ml}$ of solution sample and $4 \mathrm{ml}$ of DPPH in ethyl acetate) were performed at $517 \mathrm{~nm}$ at 0 and $30 \mathrm{~min}$. The antiradical efficiency (AE) of oils was determined according to Equation 1 (Brand-Williams et al. 1995).

$A E=1 / E C_{50}$

\section{STATISTICAL ANALYSES}

The results obtained from analytical determinations, in triplicate, were submitted to analysis of variance, and differences between means were tested at 5\% probability, by Tukey test (Gacula Jr et al. 2009), using ESTAT program, version 2.0.

\section{RESULTS AND DISCUSSION}

The levels of total carotenoids, total phenolic compounds, and tocopherols in the oils of Hamlin, Natal, Pera-rio, and Valencia seeds are shown in Table I.

The oil of Hamlin orange seeds presented the lowest amount of total carotenoids $(11.64 \mathrm{mg} / \mathrm{kg}$,

TABLE I

Total carotenoids, total phenolic compounds and $\alpha$-tocopherol of oils extracted from orange seeds.

\begin{tabular}{lccc}
\hline Varieties & TC $(\mathbf{m g} / \mathbf{k g})$ & TPC $(\mathbf{g} / \mathbf{k g})$ & $\boldsymbol{\alpha}$-tocopherol $(\mathbf{m g} / \mathbf{k g})$ \\
\hline Hamlin & $11.64 \pm 0.54^{\mathrm{c}}$ & $3.79 \pm 0.03^{\mathrm{d}}$ & $135.50 \pm 0.29^{\mathrm{b}}$ \\
Natal & $18.47 \pm 0.78^{\mathrm{b}}$ & $4.80 \pm 0.01^{\mathrm{b}}$ & $134.07 \pm 0.21^{\mathrm{c}}$ \\
Pera-rio & $26.69 \pm 0.27^{\mathrm{a}}$ & $4.91 \pm 0.01^{\mathrm{a}}$ & $137.43 \pm 0.16^{\mathrm{a}}$ \\
Valencia & $19.24 \pm 0.93^{\mathrm{b}}$ & $4.21 \pm 0.04^{\mathrm{c}}$ & $135.63 \pm 0.49^{\mathrm{b}}$ \\
\hline
\end{tabular}

The results represent the mean \pm standard deviation of the analyses performed in triplicate. Means followed by the same letter in the lines do not differ by Tukey test $(\mathrm{p}<0.05)$. TC - total carotenoids are expressed as $\beta$-carotene, TPC - total phenolic compounds are expressed as GAE equivalents. 
expressed as $\beta$-carotene) and the oil of Pera-rio orange presented the highest amount, $26.69 \mathrm{mg} /$ $\mathrm{kg}$. In Table I, it can be observed that the oils of Natal and Valencia orange seeds did not differ significantly by Tukey test $(\mathrm{p}>0.05)$, with values of $18.47 \mathrm{mg} / \mathrm{kg}$ and 19.24 milligrams of $\beta$-carotene per kilogram, respectively.

Malacrida et al. (2012) evaluated Pera-rio orange seed oils, and found levels of $0.13 \mathrm{mg} /$ $\mathrm{kg}$ and $0.19 \mathrm{mg} / \mathrm{kg}$ of lutein and $\beta$-carotene, respectively. The corn germ oil presented $5 \mathrm{mg} /$ $\mathrm{kg}$ of total carotenoids (Moreau et al. 2007). The above mentioned values are lower than the ones presented by orange seed oils in the present study.

$\mathrm{Xu}$ et al. (2008) found total carotenoids concentration of $0.08,2.92$, and $0.72 \mathrm{mg} / \mathrm{ml}$ (expressed as $\beta$-carotene) in lemon, ponkan, and Hamlin orange juices, respectively.

The content of total carotenoids in oils is affected by the maturation stage of the fruits and by their extraction and storage conditions. Oils extracted from ripe fruits may present higher amounts of carotenoid pigments, while those obtained from partially ripe fruits have higher chlorophyll concentration (Ramadan and Moserl 2003).

All oils showed important levels of total phenolic compounds: the highest content is present in the oils of Pera-rio orange seeds, $4.91 \mathrm{~g} / \mathrm{kg}$ (expressed as GAE), followed by Natal, Valencia, and Hamlin, 4.80, 4.21, and $3.79 \mathrm{~g} / \mathrm{kg}$, respectively.

Malacrida et al. (2012) studied the phytochemicals and antioxidant activity of citrus seed oils. The level of total phenolic compounds of Perario orange seed oil was determined by using the Folin-Ciocalteu reagent under the same analytical conditions, and the results were expressed as gallic acid equivalents per kilogram of oil. According to the results, this oil obtained $1.15 \mathrm{~g} / \mathrm{kg}$ of total phenolic compounds. The levels of phenolic compounds in the orange seed oils from this study were higher than those found in the oils analyzed in the mentioned study.
When analyzing lemon, ponkan, and Hamlin orange juices, Xu et al. (2008) found concentrations of total phenolic compounds of 751.82, 830.32, and $1499.71 \mathrm{~g} / \mathrm{kg}$, respectively, using the FolinCiocalteu reagent.

In soybean, sunflower, corn, canola, and rice oils, extracted by cold extraction, the quantities of total phenolic compounds were found from $126 \mathrm{~g} /$ $\mathrm{kg}$ to $148 \mathrm{~g} / \mathrm{kg}$, in caffeic acid equivalents (Siger et al. 2008) and from $0.16 \mathrm{mg} / \mathrm{kg}$ to $0.40 \mathrm{~g} / \mathrm{kg}$ in olive oil, in gallic acid equivalents (Nakbi et al. 2010).

The quantification of these substances is influenced by the nature of the compound, the method of extraction employed, as well as by the presence of interfering elements, such as waxes, terpenes, and chlorophyll. A satisfactory method for extraction of phenolics present in the samples has not been developed yet.

According to Table I, only $\alpha$-tocopherol was detected in the oils extracted from seeds of all orange varieties. Due to the fact that $\alpha$-tocopherol presents higher biological activity as vitamin $\mathrm{E}$, the oils analyzed may present vitamin activity.

Anwar et al. (2008) determined the composition of tocopherols in oils extracted from citrus species seeds (C. paradisi, C. sinensis, C. reticulata) and also obtained $\alpha$-tocopherol as the main tocopherol, 380, 220, and $557.82 \mathrm{mg} / \mathrm{kg}$, respectively.

The orange seed oils presented higher amounts of total tocopherols than babaçu oil $(60-130 \mathrm{mg} /$ $\mathrm{kg})$, similarly to that of palm stearin $(100-700 \mathrm{mg} /$ $\mathrm{kg}$ ), and lower amounts regarding soybean oil (600-3370 mg/kg) (Codex Alimentarius Commission 2009).

The phytosterols are of great interest due to their antioxidant activity and their impact on health. They are the main components of the unsaponifiable matter in oils. The analysis of sterols provides information about the quality of the oil. Phytosterols are some of the constituents of the cell wall in vegetables. When ingested, 
they reduce the absorption of cholesterol by the intestine, due to their similarity with the cholesterol molecule. In the last decades, purified phytosterols and phytostanols have been added to several foods for the obtainment of functional foods that perform hypocholesterolemic activity after ingested. The daily intake of 1.6-2.0 g/day of phytosterols and phytostanols, incorporated into these foods, is capable of reducing cholesterol absorption by the intestine in up to $30 \%$, in addition to lowering the level of plasma LDL-cholesterol in $8-10 \%$ (Marangoni and Poli 2010). The results on the amount of phytosterols of orange seed oils are displayed in Table II.

TABLE II

Amount of phytosterols of oils extracted from orange seeds.

\begin{tabular}{lcccc}
\hline \multirow{2}{*}{ Phytosterols (mg/kg) } & \multicolumn{4}{c}{ Varieties } \\
\cline { 2 - 5 } & Hamlin & \multicolumn{1}{c}{ Natal } & Pera-rio & \multicolumn{1}{c}{ Valencia } \\
\hline Cholesterol & $23.0 \pm 0.0^{\mathrm{c}}$ & $36.9 \pm 0.0^{\mathrm{a}}$ & $15.1 \pm 0.0^{\mathrm{d}}$ & $25.7 \pm 0.0^{\mathrm{b}}$ \\
Campesterol & $60.2 \pm 0.0^{\mathrm{d}}$ & $81.7 \pm 0.0^{\mathrm{a}}$ & $76.5 \pm 0.0^{\mathrm{b}}$ & $77.4 \pm 0.0^{\mathrm{c}}$ \\
$\beta$-sitosterol & $1205.3 \pm 0.0^{\mathrm{b}}$ & $1215.4 \pm 0.0^{\mathrm{a}}$ & $1203.1 \pm 0.0^{\mathrm{c}}$ & $1196.5 \pm 0.0^{\mathrm{d}}$ \\
Totals & 1288.5 & 1334.0 & 1294.7 & 1299.6 \\
\hline
\end{tabular}

The results represent the mean \pm standard deviation of the analyses performed in triplicate.

Means followed by the same letter in the lines do not differ by Tukey test $(p<0.05)$.

Only cholesterol, campesterol, and $\beta$-sitosterol were detected in the samples analyzed.

The oil of Natal orange seeds presented higher amounts of the three phytosterol isomers: 1215.4, 81.7 , and $36.9 \mathrm{mg} / \mathrm{kg}$ of $\beta$-sitosterol, campesterol, and cholesterol, respectively. This oil was the one that presented higher level of total phytosterols $(1334.0 \mathrm{mg} / \mathrm{kg})$, followed by Valencia $(1299.6 \mathrm{mg} /$ $\mathrm{kg}$ ), Pera-rio (1294.7 mg/kg), and Hamlin (1288.5 $\mathrm{mg} / \mathrm{kg}$ ) seed oils (Fig. 1).

When studying bitter melon, kalahari melon, kenaf, pumpkins, and roselle oils, Nyam et al. (2009) found levels of total phytosterols of 4643, $6416.90,3675.60,2740$, and $7575.60 \mathrm{mg} / \mathrm{kg}$, respectively. Nehdi et al. (2010), when studying Phoenix canariensis seed oils, reported 3360.70 $\mathrm{mg} / \mathrm{kg}$ of total phytosterols. In comparison to the percentage of total phytosterols in palm oil (270$800 \mathrm{mg} / \mathrm{kg}$ ), the orange seed oils contain lower amounts of these compounds (Codex Alimentarius Commission 2009).

Arena et al. (2007) obtained $100.40 \mathrm{mg} /$ $\mathrm{kg}$ of total phytosterols for pistachio seed oils. Cheikh-Rouhou et al. (2008) found levels of total phytosterols in Nigella sativa and Pinus halepensis seed oils of $281 \mathrm{mg} / \mathrm{kg}$ and $735 \mathrm{mg} / \mathrm{kg}$. Such values are lower than those of orange seed oils.

It is important to note that the content of phytosterols detected in samples may vary depending on the chromatographic conditions employed, such as the programming of the temperature column, the temperatures used in the injector and in the detector, the carrier gas speed, among other.

The antioxidant activity (\%), the value of necessary concentration of the oil, in order to reduce the free radicals $\left(\mathrm{EC}_{50}\right)$ in $50 \%$, and the antiradical efficiency, are presented in Table III.

It can be observed that all the orange seed oils showed DPPH' radical scavenging activity. However, the oil of Pera-rio orange seeds was the most effective, presenting antioxidant activity of $70.2 \%$. The other oils presented antioxidant activity of 59.9, 58.9, and 56.0\%, in Valencia, Natal, and Hamlin orange varieties, respectively.

The amount of oil necessary to decrease the initial concentration of $\mathrm{DPPH}^{\circ}$ by $50 \%\left(\mathrm{EC}_{50}\right)$ ranged from $35.08 \mathrm{~kg}$ to $38.31 \mathrm{~kg}$ of oil per kilogram of DPPH: 
956

NEUZA JORGE, ANA CAROLINA DA SILVA and CAROLINE P.M. ARANHA

The oils of Pera-rio orange seeds presented the highest value for antiradical efficiency (2.79), which was determined by using $\mathrm{EC}_{50}$ value. The other oils studied obtained similar values: 2.61, 2.68, and 2.69, for Valencia, Natal, and Hamlin varieties, respectively.

a

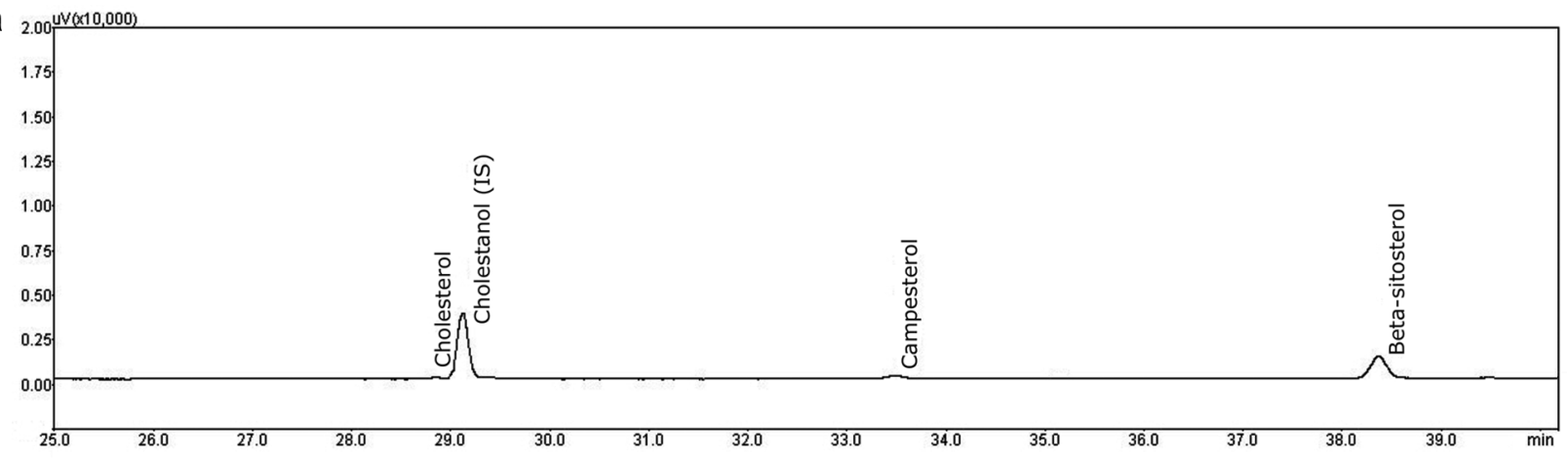

b

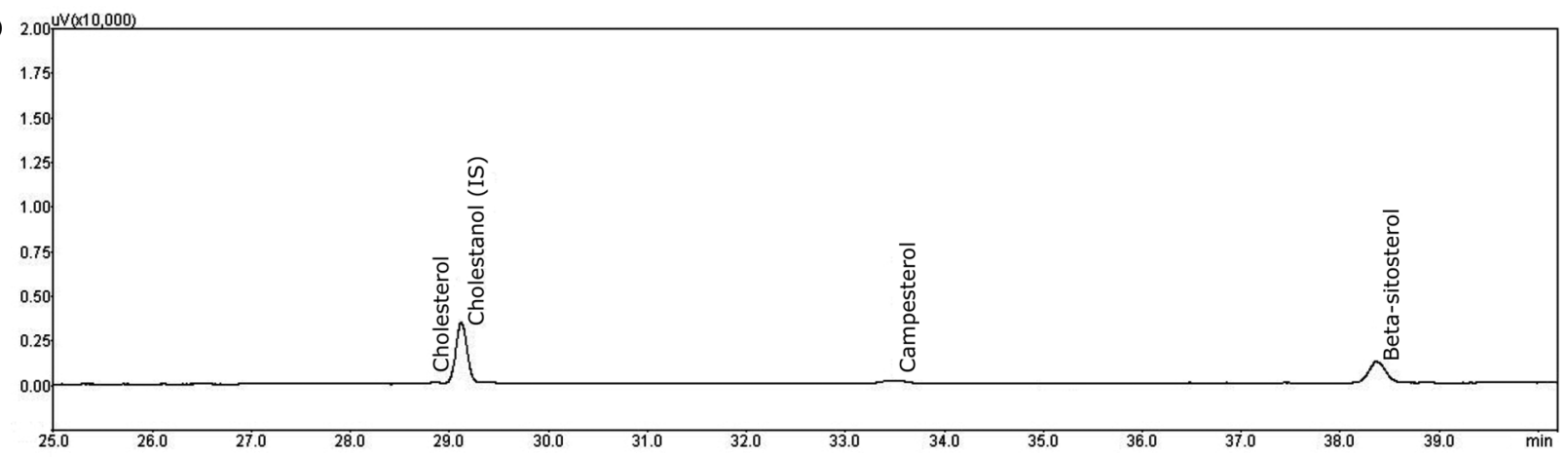

C 2.00 w $(x \times 10,000)$

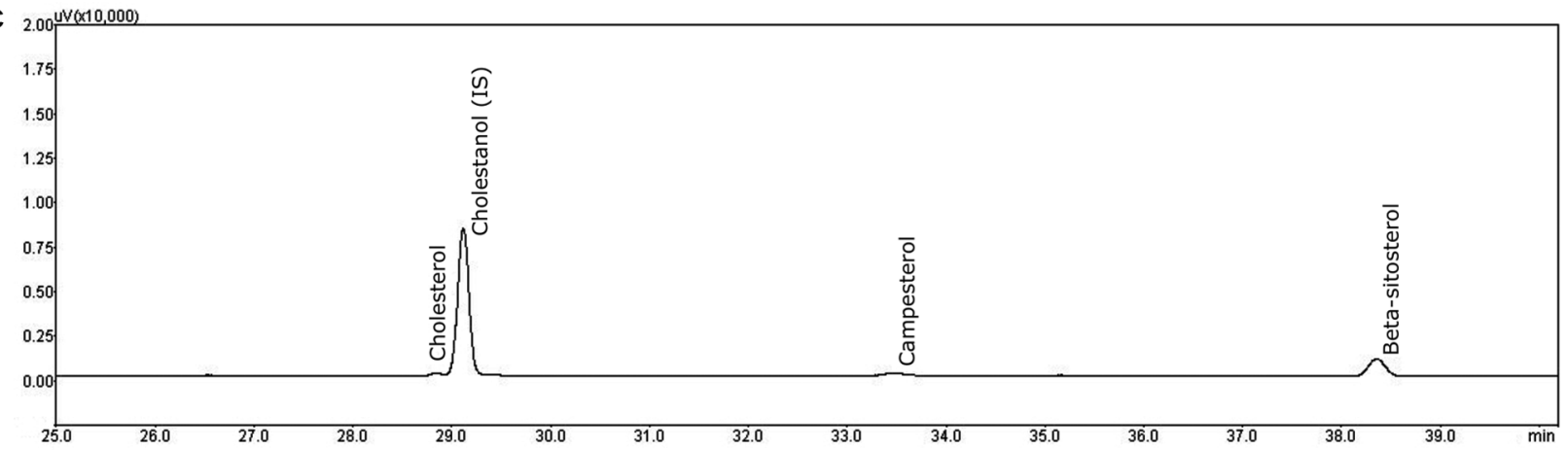

d 2.00 W(x10,000)

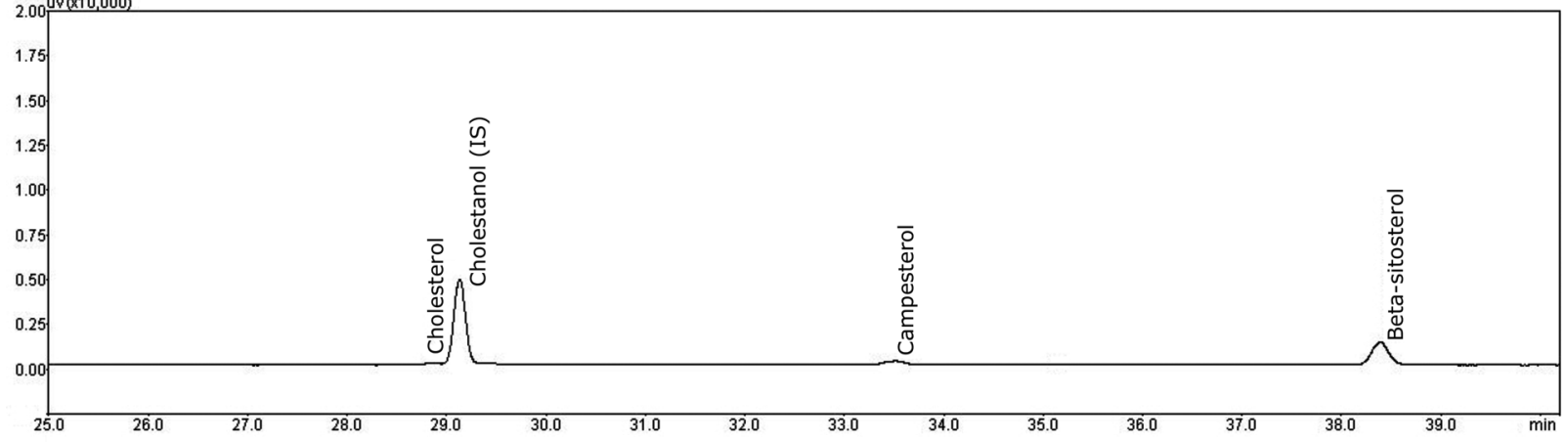

Figure 1 - Chromatograms of phytosterolsof oils extracted from orange seeds: Hamlin (a), Natal (b), Pera-rio (c) and Valencia (d).

An Accad Bras Cienc (2016) $\mathbf{8 8}$ (2) 
TABLE III

Antioxidant activity, $\mathrm{EC}_{50}$ and antiradical efficiency of oils extracted from orange seeds.

\begin{tabular}{lccc}
\hline Varieties & Antioxidant activity $(\%)$ & $\begin{array}{c}\mathrm{EC}_{50} \\
(\mathrm{~kg} / \mathrm{kg})\end{array}$ & Antiradical efficiency \\
\hline Hamlin & $58.9 \pm 0.7^{\mathrm{b}}$ & 37.19 & $2.69 \times 10^{-2}$ \\
Natal & $56.0 \pm 0.5^{\mathrm{b}}$ & 37.25 & $2.68 \times 10^{-2}$ \\
Pera-rio & $70.2 \pm 0.4^{\mathrm{a}}$ & 35.08 & $2.79 \times 10^{-2}$ \\
Valencia & $59.9 \pm 1.0^{\mathrm{c}}$ & 38.31 & $2.61 \times 10^{-2}$ \\
\hline
\end{tabular}

The results represent the mean \pm standard deviation of the analyses performed in triplicate. Means followed by the same letter in the column do not differ by Tukey test $(\mathrm{p}<0.05)$. $\mathrm{EC}_{50}$ is defined as the sufficient concentration to obtain $50 \%$ of the maximum effect estimated in $100 \%$ (expressed in kilograms of oil per kilogram of $\mathrm{DPPH}^{\circ}$ ).

Malacrida et al. (2012), while evaluating the antioxidant activity of citrus oils, found the highest antioxidant activity from the oil obtained from Pera-rio orange seeds $(54.2 \%)$. The orange seed oil presented higher $\mathrm{DPPH}^{\bullet}$ scavenging activity among the analyzed oils reaching $47.6 \%$ of the $\mathrm{DPPH}^{\circ}$ in the reaction mixture. The orange oil also showed the best $\mathrm{EC}_{50}\left(10.75 \mathrm{~g}\right.$ oil $\left./ \mathrm{g} \mathrm{DPPH}^{\circ}\right)$ and antiradical efficiency $\left(9.30 \times 10^{-2}\right)$. The levels of antioxidant activity and $\mathrm{EC}_{50}$ in the orange seed oils were higher than in the oils analyzed in the mentioned study.

The antioxidant activity was significantly correlated to the level of $\alpha$-tocopherol $(r=0.81)$, which indicates that the oils with higher concentrations of $\alpha$-tocopherol presented higher radical scavenging activity.

\section{CONCLUSIONS}

All oils analyzed in this study presented considerable amounts of carotenoids, phenolic compounds, $\alpha$-tocopherol, and phytosterols, thus they may be good sources of these compounds. The oils analyzed showed free radical scavenging capacity. The antiradical efficiency of the oils analyzed followed a decreasing order: Pera-rio $>$ Hamlin $=$ Natal $>$ Valencia. Such fact may add value to wastes from orange processing, increasing the viable sources for obtainment of specialty oils.

\section{ACKNOWLEDGMENTS}

To Conselho Nacional de Desenvolvimento Científico e Tecnológico - CNPq, $\left(\right.$ process $n^{\circ}$ 555870/2010-3) for their financial support.

\section{RESUMO}

Devido ao aumento da produção mundial de alimentos com consequente aumento de produção de resíduos, verifica-se a importância do desenvolvimento de pesquisas para o aproveitamento dos mesmos. Assim, o interesse em óleos vegetais com compostos bioativos, como os obtidos a partir de sementes de frutas, está crescendo. Portanto, o presente estudo teve como objetivo caracterizar os óleos extraídos a partir de sementes de laranja (Citrus sinensis), das variedades Hamlin, Natal, Pera-rio e Valencia, e determinar os níveis de carotenoides totais, compostos fenólicos totais, tocoferóis e fitoesteróis bem como determinar as suas atividades antioxidantes. Os óleos de sementes de laranja apresentaram conteúdo importante de carotenoides totais $(19,01 \mathrm{mg} / \mathrm{kg})$, compostos fenólicos totais $(4,43 \mathrm{~g} / \mathrm{kg})$, $\alpha$-tocoferol $(135,65 \mathrm{mg} / \mathrm{kg})$ e fitoesteróis $(1304,2 \mathrm{mg} /$ $\mathrm{kg}$ ). A atividade antioxidante variou de 50,0\% (Natal) a $70,2 \%$ (Pera-rio). De acordo com os resultados obtidos, é possível concluir que os óleos das sementes de laranja podem ser usados como óleos especiais na dieta, uma vez que contêm quantidades substanciais de compostos bioativos e antioxidantes.

Palavras-chave: resíduo agroindustrial, fitosteróis, tocoferóis, óleos vegetais. 


\section{REFERENCES}

ANWAR F, NASEER R, BHANGER MI, ASHRAF S, TALPUR FN AND AladedunYe FA. 2008. Physico-chemical characteristics of citrus seeds and seed oils from Pakistan. J Am Oil Chem Soc 85: 321-330.

AOCS - AMERICAN OIL CHEMITS' SOCIETY. 2009. Official and Tentative Methods of the American Oil Chemists' Society: including additions and revisions. $6^{\text {th }}$ ed., Champaing: AOCS Press.

ARENA E, CAMPISI S, FALliCo B AND MACCARONE E. 2007. Distribution of fatty acids and phytosterols as a criterion to discriminate geographic origin of pistachio seeds. Food Chem 104: 403-408.

BRAND-WILliAMS W, CUVELIER ME AND BERSET C. 1995. Use of a free radical method to evaluate antioxidant activity. LWT - Food Sci Technol 28: 25-30.

Cheikh-Rouhou S, Besbes S, Lognay G, Blecker C, DEROANNE C AND ATTIA H. 2008. Sterol composition of black cumin (Nigella sativa L.) and Aleppo pine (Pinus halepensis Mill.) seed oils. J Food Comp Anal 21: 162-168.

CodeX Alimentarius Commission. 2009. Codex-Stan 210: codex standard for named vegetable oils. FAO/WHO, Rome, Italy.

Duchateau GSMJE, BAUER-PLANK CG, LOUTER AJH, VAN DER HAM M, BOERMA JA, VAN ROOIJEN JJM AND ZAMDBELT PA. 2002. Fast and accurate method for total 4-desmethyl sterol content in spreads, fat-blends, and raw materials. J Am Oil Chem Soc 79: 273-278.

GACUla JR M, Singh J, Bi J AND Altan S. 2009. Statistical methods in food and consumer research. $2^{\text {nd }}$ ed., London: Academic Press, 888 p.

Hernández-MONTOYA V, MONTES-MORÁN MA AND ELIZALDE-GONZÁLEZ MP. 2009. Study of the thermal degradation of citrus seeds. Biomass Bioenerg 33: 951299.

Kalantzakis G, BleKas G, PEGKLidou K AND Boskou D. 2006. Stability and radical-scavenging activity of heated olive oil and other vegetable oils. Eur J Lipid Sci Tech 108: 329-335.

KOLLER OC. 2006. Citricultura: 1. Laranja: Tecnologia de produção, pós-colheita, industrialização e comercialização. Porto Alegre: Cinco Continentes, 400 p.
MALACRIDA CR, KimurA M AND JORGE N. 2012. Phytochemicals and antioxidant activity of citrus seed oils. Food Sci Tech Res 18: 399-404.

MARANGONI F AND POLI A. 2010. Phytosterols and cardiovascular health. Pharmacol Res 61: 193-199.

Moreau RA, JOHnston DB AND HiCKS KB. 2007. A comparison of the levels of lutein and zeaxanthin in corn germ oil, corn fiber and corn kernel oil. J Am Oil Chem Soc 84: 1039-1044.

NAKBI A, ISSAOUI M, DABBOU S, KoubAA N, ECHBILI A, HAMMAMI M AND ATTIA N. 2010. Evaluation of antioxidant activities of phenolic compounds from two extra virgin olive oils. J Food Comp Anal 23: 711-715.

NeHDi I, OMRI S, KHALIL MI AND AL-RESAYES SI. 2010. Characteristics and chemical composition of date palm (Phoenix canariensis) seeds and seed oil. Ind Crop Prod 32: 360-365.

NYAM KL, TAN CP, LAI OM, LONG K AND MAN YC. 2009. Physicochemical properties and bioactive compounds of selected seed oils. LWT - Food Sci Technol 42: 1396-1403.

PARRY J, SU L, LUTHER M, ZHOU K, YURAWECZ MP, WHITTAKER P AND YU L. 2005. Fatty acid composition and antioxidant properties of cold-pressed marionberry, boysenberry, red raspberry, and blueberry seed oils. J Agr Food Chem 53: 566-573.

RAMADAN MF AND MOSERL JT. 2003. Oil cactus pear (Opuntia fícus-indica L.). Food Chem 82: 339-345.

RODRIGUEZ-AMAYA DB. 1999. A guide to carotenoids analysis in food. Washington: ILSI Press.

Schieber A, Stintzing F AND CARLE R. 2001. Byproducts of plant food processing as a source of functional compounds: recent developments. Trends Food Sci Tech 12: 401-413.

SCHMIDT S AND POKORNÝ J. 2005. Potential application of oil seeds as sources of antioxidants for food lipids - a review. Czech J Food Sci 23: 93-102.

SIGER A, NOGALA-KALUCKA M AND LAMPART-SZCZAPA E. 2008. The content and antioxidant activity of phenolic compounds in cold-pressed plant oils. J Food Lipids 15: 137-149.

SINGLETON VL AND ROSSI JA. 1965. Colorimetry of total phenolics with phosphomolybdic and phosphotungstic acid reagents. Am J Enol Viticult 16: 144-158.

XU G, LIU D, Chen J, Ye X, MA Y AND SHI J. 2008. Juice components and antioxidant capacity of citrus varieties cultivated in China. Food Chem 106: 545-551. 